\title{
Unconventional fiscal policy
}

by Francesco D'Acunto, Daniel Hoang and Michael Weber

No. 114 | JANUARY 2018

\section{WORKING PAPER SERIES IN ECONOMICS}

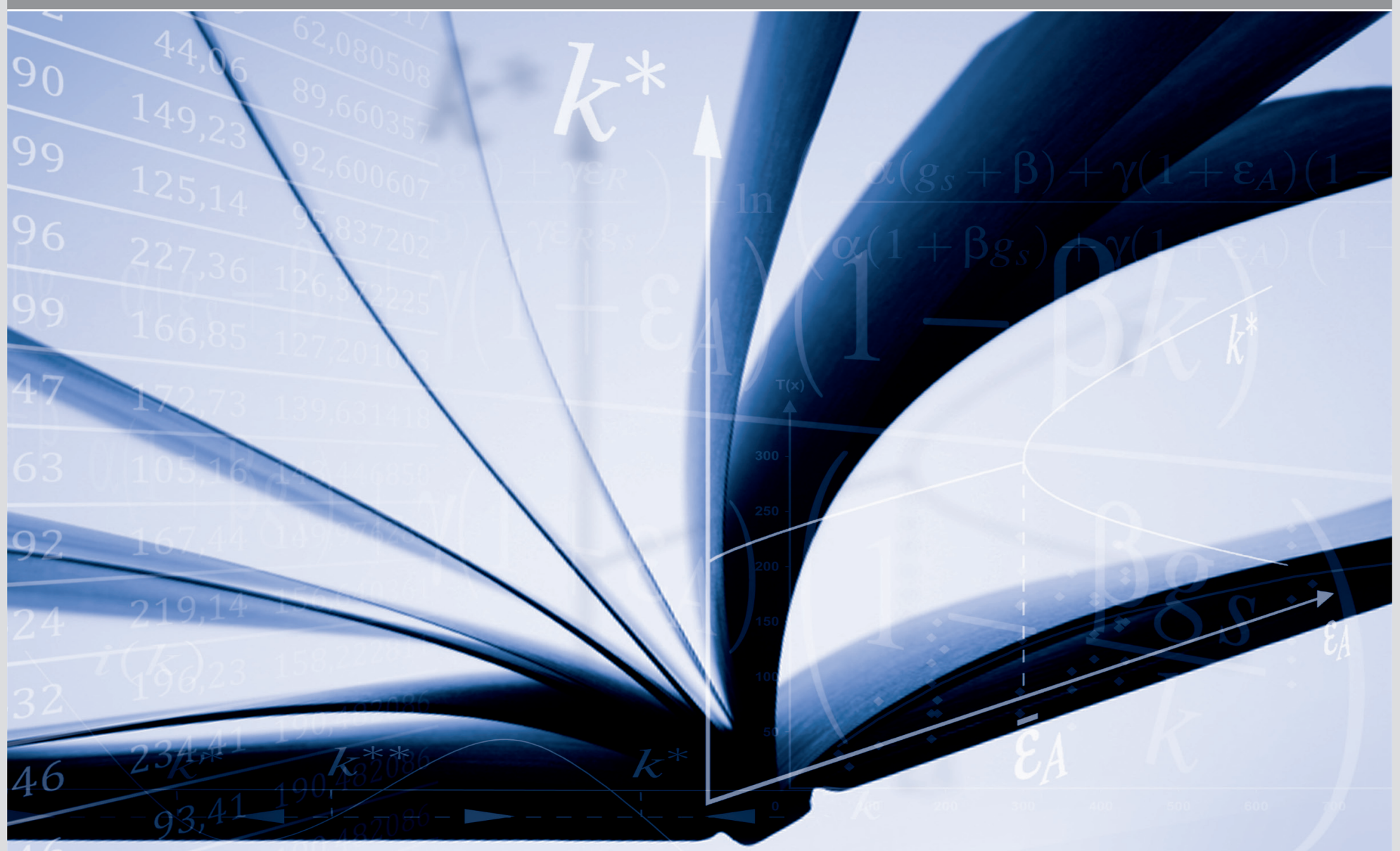




\section{Impressum}

Karlsruher Institut für Technologie (KIT)

Fakultät für Wirtschaftswissenschaften

Institut für Volkswirtschaftslehre (ECON)

Kaiserstraße 12

76131 Karlsruhe

KIT - Die Forschungsuniversität in der Helmholtz-Gemeinschaft

Working Paper Series in Economics

No. 114, January 2018

ISSN 2190-9806

econpapers.wiwi.kit.edu 


\title{
Unconventional Fiscal Policy
}

\author{
By Francesco D'Acunto, Daniel Hoang, and Michael Weber*
}

Macroeconomists often prefer monetary policy to fiscal policy as a tool to stabilize business cycles. Fiscal policy is typically only effective with a lag, and results in permanent deficits with higher nominal interest rates and distortionary taxes. In addition, a high marginal propensity to save out of temporary tax cuts might result in low fiscal multipliers with empirical estimates often below 1 (see Ramey (2011b) and Barro and Redlick (2011)). ${ }^{1}$

The zero lower bound on nominal interest rates, however, constrains the effectiveness of monetary policy during liquidity traps. Large stocks of sovereign debt limit the scope of fiscal stimulus, and inflated central bank balance sheets constrain assetpurchase programs as forms of unconventional monetary policy. ${ }^{2}$ The unclear effectiveness of several measures of monetary policy - both conventional and unconventional - after the 2008-2009 Financial Crisis calls for alternative mechanisms to in-

\footnotetext{
* D'Acunto: R.H.Smith School of Business, University of Maryland, College Park, MD, USA. eMail: fdacunto@rhsmith.umd.edu. Hoang: Department for Finance and Banking, Karlsruhe Institute of Technology, Karlsruhe, B-W, Germany. e-Mail: daniel.hoang@kit.edu. Weber: Booth School of Business, University of Chicago, Chicago, IL, USA and NBER. This research was conducted with restricted access to Gesellschaft für Konsumforschung (GfK) data. The views expressed here are those of the authors and do not necessarily reflect the views of GfK. We thank the project coordinator at GfK, Rolf Buerkl, for help with the data and insightful comments. We also thank Rudi Bachmann, Oli Coibion (discussant), Yuriy Gorodnichenko, Valerie Ramey, Harald Uhlig, and conference participants at the 2018 AEA session on Conventional and Unconventional Fiscal Multipliers. Weber thanks the Cohen Keenoy Foundation for financial support.

${ }^{1}$ Researchers debate the size and state dependence of fiscal multipliers (see Auerbach and Gorodnichenko (2012) and Owyang, Ramey and Zubairy (2013)). Ramey (2011a) and Ramey (2015) review this literature.

${ }^{2}$ Caballero, Farhi and Gourinchas (2015) develop a model in which liquidity traps spread around the world, and secular stagnation can be the new norm for global macroeconomic conditions.
}

crease aggregate demand and hence promote growth.

This issue is especially relevant for several major developed economies that, years after the end of the Great Recession in the United States, are still experiencing sluggish growth. In particular, southern European countries are still facing the contractionary effects of the austerity measures they implemented to abate their debt-toGDP ratios during the Euro sovereign-debt crisis. Many economists argue structural reforms are necessary to improve the competitiveness of these countries in the long run, but promoting a short-run increase in aggregate demand to jump start the economy is also a compelling objective for policy makers.

The conundrum the Euro area has faced since the start of the Great Recession is to generate inflation and ultimately stimulate consumption and economic growth in a setting in which traditional monetary policy measures were not viable and governments could not generate growth with fiscal stimulus because of their large debt-to-GDP ratios. This challenge was so compelling that in his Marjolin lecture on February 4, 2016, the president of the European Central Bank, Mario Draghi, asserted that "there are forces in the global economy that are conspiring to hold inflation down." (Draghi, 2016).

\section{What Is Unconventional Fiscal Policy?}

In this article, we define and propose preliminary empirical evidence for an alternative type of policy measure, which we call unconventional fiscal policy. We define unconventional fiscal policies as those policies that generate an increasing path of consumption taxes that result in households' higher inflation expectations and negative real interest rates. Negative real interest 
rates can stimulate household consumption, and result in increased spending, and ultimately higher growth. Thus, the main objective of unconventional fiscal policies is to increase households' inflation expectations even when conventional monetary policy is constrained.

Unconventional fiscal policy satisfies the following criteria:

1. It is time consistent, because it replicates the first-best allocation in a setting in which lump-sum taxes are available.

2. It does not rely on inefficient policies such as commitments to keep future interest rates low or wasteful government spending.

3. It does not rely on income effects, which might be small.

4. It can be implemented in a budgetneutral fashion, which is especially relevant for countries plagued by large debt-to-GDP ratios.

5. It is a policy measure that is salient and easy to understand by households.

Theoretical underpinnings for unconventional fiscal policy are in Correia et al. (2013), who show the use of consumption taxes can replicate negative real interest rates and completely offset the zero-lowerbound constraint on nominal interest rates in a time-consistent manner. The intuition for the result is simple. Suppose real interest rates should be negative. Nominal interest rates typically cannot be negative due to the arbitrage relationship between money and bonds, and hence the only way to generate negative real interest rates is higher inflation. Consumer prices determine the households' intertemporal decisions. Implementing an increasing path of future consumption taxes generates consumer price inflation and negative real interest rates, which stimulate demand.

If firms set prices in a staggered fashion, additional taxes might be necessary to achieve a first-best allocation. We might have to lower labor income taxes to ensure consumption taxes do not affect the intratemporal margin between leisure and consumption, and hence the real wage. The constant real wage and the fact that firms' pricing decisions are independent of the change in consumption taxes ensures firms have no incentive to change prices, which avoids costly price dispersion. Therefore, the production allocation across firms is efficient and the government can use taxes to offset the possible distortions due to monopoly rents. Under certain conditions, these policies can replicate the first-best allocation and are hence time consistent.

Based on the criteria listed above, unconventional fiscal policy differs markedly from traditional forms of fiscal policy, such as fiscal stimulus and tax rebates. For instance, traditional measures of fiscal policy are not budget neutral, but produce higher budget deficits. Moreover, traditional forms of fiscal policy rely heavily on income effects, which might be small and stimulate only temporary demand, as the example of the cash for clunkers program in the United States demonstrates (see, e.g., Mian and Sufi (2012)).

Unconventional fiscal policy also differs markedly from unconventional monetary policy measures, such as forward guidance, which also operate through inflation expectations but might be difficult to understand and actually increase savings because they might increase uncertainty and induce precautionary savings.

\section{Unconventional Fiscal Policy: A Case Study}

A concrete example of a measure of unconventional fiscal policy is the announcement of future value-added tax (VAT) increases. Among the criteria this policy tool fulfills, the salience of this type of policy measure to generate inflation expectations among non-experts, such as households, is a crucial advantage of unconventional fiscal policy over unconventional monetary policy. $^{3}$

Shapiro (1991), Feldstein (2002), and Hall (2011) propose pre-announced increases in VAT to generate consumer price inflation and stimulate spending via intertemporal substitution without increas-

\footnotetext{
${ }^{3}$ See D'Acunto et al. (2017) for a discussion of the relationship between the salience of consumer prices and inflation expectations.
} 
ing the federal budget deficit. ${ }^{4}$

Testing for the effect of unconventional fiscal policy on households' consumption expenditure empirically poses two main challenges. First, the econometrician needs to observe households' consumption plans in conjunction with a large set of expectations regarding future personal and macroeconomic conditions, including inflation expectations. This setup is crucial because unconventional fiscal policy operates through households' inflation expectations as opposed to channels such as income or wealth effects.

Second, a generic change in consumption taxes does not necessarily represent a measure of unconventional fiscal policy. Viable measures require an exogenous preannouncement of higher future consumption taxes. The announcement should happen when nominal interest rates are fixed, so that higher inflation expectations result in lower real interest rates, and hence households' lower willingness to save. Fixed nominal interest rates can arise if the zero lower bound binds, or if the central bank does not necessarily respond to unilateral governmental policies, such as in a currency union.

In this article, we propose Poland as a case study. We use confidential micro data from the market research firm GfK. GfK surveys a representative set of 1,000 Polish households on a monthly basis to measure expectations about business-cycle conditions on behalf of the European Commission. The Polish administration announced in July 2010 that it would increase the general VAT from $22 \%$ to $23 \%$ and the reduced rate to $8 \%$. We use the answers to the questions regarding how consumer prices will evolve in the next 12 months relative to the previous 12 months and whether households think it's a good time to buy larger items, such as furniture and electronic items, given the current economic conditions, to test for the effect of uncon-

\footnotetext{
${ }^{4}$ Feldstein (2002): "This [VAT] tax-induced inflation would give households an incentive to spend sooner rather than waiting until prices are substantially higher."
}

ventional fiscal policy on consumption expenditure. ${ }^{5}$

Based on a sample from January 2009 through December 2012, Figure 1 documents a positive time-series correlation between Polish households' average inflation expectations and their willingness to purchase durable goods. The positive correlation is statistically different from zero throughout the sample period. Its size is larger after the announcement (July 2010) and before the actual VAT increase (January 2011).

Figure 1 is consistent with the consumption Euler equation as well as with the potential effectiveness of unconventional fiscal policy. At the same time, though, this baseline association is also consistent with alternative explanations and channels. ${ }^{6}$

The ideal experiment would consist of an exogenous increase in future consumption taxes with no other contemporaneous shock. The Polish experiment is thus far from perfect: (i) the tax change was not exogenous based on the taxonomy of Romer and Romer (2010); (ii) the period of the change coincided with the European sovereign debt crisis; (iii) the Polish government implemented several contemporaneous policy changes; (iv) Poland had monetary sovereignty to change nominal interest rates over the period of interest; and (v) channels other than inflation expectations might explain our findings, such as income or wealth effects, redistribution, consumer uncertainty, or housing-wealth effects.

In addition, all Polish households were exposed to the same shock. For identification, we miss a counterfactual, that is, a group of households not affected by the shock but similar to Polish households before the shock.

In D'Acunto, Hoang and Weber (2018), we address all these challenges and exploit a unique natural experiment in Ger-

\footnotetext{
${ }^{5}$ See D'Acunto, Hoang and Weber (2018) for the exact wording and variable construction.

${ }^{6}$ The size and sign of the association between inflation expectations and consumption propensities is still debated. See, e.g., Bachmann, Berg and Sims (2015), Burke and Ozdagli (2014), Crump et al. (2015), and D'Acunto, Hoang and Weber (2018).
} 


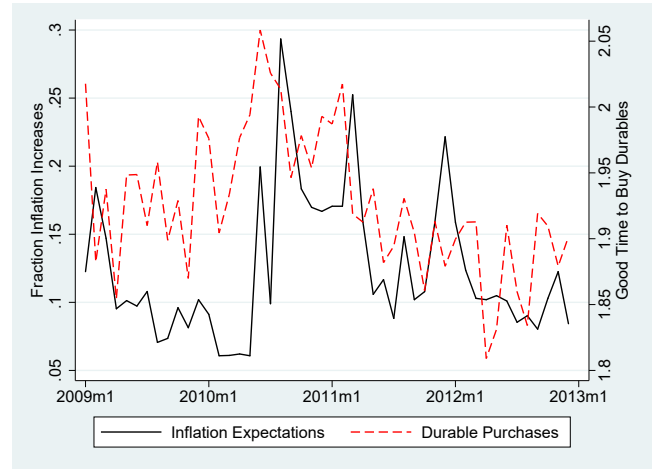

Figure 1. Expected Increase in Inflation and Average Readiness to Spend on Durables

Note: This figure plots average monthly inflation expectations (black solid line, left y-axis) and the average monthly readiness to purchase durables (red dashed line, right y-axis) over time. We use the confidential micro data underlying the GfK Consumer Climate survey to construct these variables. GfK asks a representative sample of 1,000 households how consumer prices will evolve in the next 12 months compared to the previous 12 months and whether it is a good time to purchase durables given the current economic conditions. We create a dummy variable that equals 1 when a household expects inflation to increase. Higher values correspond to better times to purchase durables. The sample period is January 2009 to December 2012 for a total of four years.

many that fulfills our definition of unconventional fiscal policy. In November 2005, the newly formed German government unexpectedly announced a three-percentagepoint increase in VAT, effective in January 2007.

Two features make this announcement uniquely suited to test for the effect of unconventional fiscal policy, compared to other changes in VAT. First, the European Union (EU) imposed this measure on the German administration to avoid an infringement procedure for the breach of the Maastricht Treaty. The VAT increase announcement was therefore unexpected and unrelated to expected future economic conditions, which qualifies as an exogenous tax change due to inherited fiscal deficits in Romer and Romer (2010). Second, Germany had no monetary sovereignty in 2010. The European Central Bank excluded explicitly any increases in nominal interest rates to counteract the price pressure from a higher VAT in Germany.

To create a counterfactual, D'Acunto, Hoang and Weber (2018) proposes a strategy in the spirit of Poterba (1996) and Besley and Rosen (1999). The empirical design uses matched households in EU countries not exposed to the VAT shock as a counterfactual for German households, in a difference-in-differences identification strategy.

\section{Concluding Remarks}

In this paper, we provide preliminary empirical evidence of the effectiveness for a novel form of stimulus - unconventional fiscal policy - that we argue has many desirable properties compared to conventional fiscal policy or unconventional monetary policy. Pre-announced VAT increases combined with lower income taxes-including tax credits-would result in a predictable increase in inflation without inducing uncertainty. They would increase consumer spending and hence growth, but would not lead to higher budget deficits, without affecting the total tax burden of households. These implications are especially relevant at times of low inflation and low growth, paired with the non-viability of conventional measures of monetary and fiscal policy. Governments could reverse the tax changes during normal economic times to keep the gunpowder dry for potential subsequent economic slumps.

\section{REFERENCES}

Auerbach, Alan J, and Yuriy Gorodnichenko. 2012. "Measuring the out- 
put responses to fiscal policy." American Economic Journal: Economic Policy, 4(2): 1-27.

Bachmann, Ruediger, Tim O. Berg, and Eric Sims. 2015. "Inflation Expectations and Readiness to Spend: Cross-Sectional Evidence." American Economic Journal: Economic Policy, 7(1): 1-35.

Barro, Robert J., and Charles J. Redlick. 2011. "Macroeconomic Effects From Government Purchases and Taxes." The Quarterly Journal of Economics, 126(1): 51-102.

Besley, Timothy J, and Harvey S Rosen. 1999. "Sales taxes and prices: an empirical analysis." National Tax Journal, 52(2): 157-178.

Burke, Mary A, and Ali Ozdagli. 2014. "Household Inflation Expectations and Consumer Spending: evidence from Panel Data." Unpublished Manuscript, Federal Reserve Bank of Boston, 13(25): 1-43.

Caballero, Ricardo J, Emmanuel Farhi, and Pierre-Olivier Gourinchas. 2015. "Global Imbalances and Currency Wars at the ZLB." National Bureau of Economic Research.

Correia, Isabel, Emmanuel Farhi, Juan Pablo Nicolini, and Pedro Teles. 2013. "Unconventional Fiscal Policy at the Zero Bound." American Economic Review, 103(4): 1172-1211.

Crump, Richard K, Stefano Eusepi, Andrea Tambalotti, and Giorgio Topa. 2015. "Subjective intertemporal substitution." FRB of New York Staff Report, , (734).

D'Acunto, F., D. Hoang, and M. Weber. 2018. "The Effect of Unconventional Fiscal Policy on Consumption Expenditure." Unpublished manuscript, University of Chicago Booth School of Business.

D'Acunto, F., U. Malmendier, J. Ospina, and M. Weber. 2017. "Salient
Price Changes, Ination Expectations, and Household Behavior." Unpublished manuscript, University of Chicago Booth School of Business.

Feldstein, Martin. 2002. "The role for discretionary fiscal policy in a low interest rate environment." National Bureau of Economic Research.

Hall, Robert E. 2011. "The Long Slump." American Economic Review, 101(2): 431-469.

Mian, Atif, and Amir Sufi. 2012. "The Effects of Fiscal Stimulus: Evidence from the 2009 Cash for Clunkers Program." The Quarterly Journal of Economics, 127(3): 1107-1142.

Owyang, Michael T, Valerie A Ramey, and Sarah Zubairy. 2013. "Are government spending multipliers greater during periods of slack? Evidence from twentieth-century historical data." The American Economic Review, 103(3): 129-134.

Poterba, James M. 1996. "Retail price reactions to changes in state and local sales taxes." National Tax Journal, 49(2): 165-176.

Ramey, Valerie A. 2011a. "Can government purchases stimulate the economy?" Journal of Economic Literature, 49(3): 673-685.

Ramey, Valerie A. 2011b. "Identifying Government Spending Shocks: It's all in the Timing." The Quarterly Journal of Economics, 126(1): 1-50.

Ramey, Valerie A. 2015. "Macroeconomic shocks and their propagation." Handbook of Macroeconomics, forthcoming.

Romer, Christina D, and David H Romer. 2010. "The Macroeconomic Effects of Tax Changes: Estimates Based on a New Measure of Fiscal Shocks." The American Economic Review, 100(3): 763-801.

Shapiro, Matthew D. 1991. "Economic Stimulant." New York Times. 


\section{Working Paper Series in Economics}

recent issues

No. 114 Francesco D’Acunto, Daniel Hoang and Michael Weber: Unconventional fiscal policy, January 2018

No. 113 Alberto Bucci, Levent Eraydın, Moritz Müller: Dilution effects, population growth and economic growth under human capital accumulation and endogenous technological change, January 2018

No. 112 Jochen Schweikert and Markus Höchstötter: Epidemiological spreading of mortgage default, January 2018

No. 111 Armin Falk and Nora Szech: Diffusion of being pivotal and immoral outcomes, December 2017

No. 110 Leonie Kühl and Nora Szech: Physical distance and cooperativeness towards strangers, November 2017

No. 109 Deniz Dizdar, Benny Moldovanu and Nora Szech: The multiplier effect in two-sided markets with bilateral investments, November 2017

No. 108 Andranik S. Tangian: Policy representation by the 2017 Bundestag, September 2017

No. 107 Andranik S. Tangian: Policy representation by German parties at the 2017 federal election, September 2017

No. 106 Andranik S. Tangian: Design and results of the third vote experiment during the 2017 election of the Karlsruhe Institute of Technology student parliament, September 2017

No. 105 Markus Fels: Incentivizing efficient utilization without reducing access: The case against cost-sharing in insurance, July 2017

No. 104 Andranik S. Tangian: Declining labor-labor exchange rates as a cause of inequality growth, July 2017 